\title{
Correction to: Efficiency of Green Inhibitors Against Hydrogen Embrittlement on Mechanical Properties of Pipe Steel API 5L X52 in Hydrochloric Acid Medium
}

\author{
M. Soudani ${ }^{1} \cdot$ M. Hadj Meliani ${ }^{1,2} \cdot$ K. El-Miloudi $^{1} \cdot$ O. Bouledroua ${ }^{1} \cdot$ C. Fares $^{1} \cdot$ M. A. Benghalia ${ }^{1} \cdot$ Z. Azari $^{2} \cdot$ J. Capelle $^{2}$. \\ Ahmad A. Sorour $^{3}$. G. Pluvinage ${ }^{2}$
}

Published online: 13 November 2018

(c) Springer Nature Switzerland AG 2018

\section{Correction to: \\ Journal of Bio- and Tribo-Corrosion (2018) 4:36 \\ https://doi.org/10.1007/s40735-018-0153-0}

In the Introduction section of the article, the reference to the study referred to in the following sentence is missing: Table 1 shows some reported results that highlight the difference in efficiency between synthetic corrosion inhibitors from a study conducted at production aerial facilities of crude gas in Hassi R'Mel field (Algeria) [1].

In addition, the photo credit for Fig. 1 is missing. The images are from a Master Thesis by Gharbi Kheira, Ouargla University, Algeria (2015) [2].

\section{Reference}

1. Gharbi K, Benyounes K, Chouicha S (2016) Corrosion and protection of crude gas production facilities in HASSI R'mel field. Fract' 3 conference

2. Gharbi K (2015) Etude de corrosion et protection des équipements de production du gaz brut à HASSI R'mel. Master thesis. University of Ouargla
The original article can be found online at https://doi.org/10.1007/ s40735-018-0153-0.

M. Hadj Meliani

m.hadjmeliani@univ-chlef.dz

1 LPTPM, Faculty of Exact Sciences and Informatics, Hassiba BenBouali University of Chlef, B.O.Box. 151, Hay-Esalem, 02000 Chlef, Algeria

2 LE3M, University of Lorraine, Îlea of Saulcy, 57045 Metz, France

3 Center of Research Excellence in Corrosion (CoRE-C), King Fahd University of Petroleum \& Minerals, P.O. Box 5040, Dhahran 31261, Saudi Arabia 